\title{
EFEKTIFITAS PENDIDIKAN KESEHATAN DENGAN MODEL WORD SQUARE TERHADAP KETERAMPILAN PEMERIKSAAN PAYUDARA SENDIRI (SADARI) DI DESA GEMBOL, NGAWI
}

\author{
The Effectiveness Of Health Education With The Word Square Model Towards \\ Own Breast Self Examination Skills (BSE) In Gembol Village, Ngawi
}

Aris Widiyanto $^{1 *}$, Krisnanda Aditya Pradana ${ }^{2}$, Yuly Peristiowati ${ }^{3}$, Agusta Dian Ellina $^{3}$, Joko Tri Atmojo ${ }^{1}$, Asruria Sani Fajriah ${ }^{3}$, Rina Tri Handayani ${ }^{1}$,

${ }^{1)}$ STIKES Mamba ul Ulum Surakarta, Jl. Ring Road Utara, Tawangsari, Mojosongo, Jebres, Kota Surakarta, Jawa Tengah, Indonesia 57127

${ }^{2}$ RSUD dr. Sayidiman Magetan, Jl. Pahlawan, No.2, Tambran, Magetan, Jawa Timur, Indonesia 63318

${ }^{3)}$ IIK STRADA Indonesia, Jl. Manila No. 37, Tosaren, Pesantren, Kota Kediri, Jawa Timur, Indonesia 64113

*widiyanto.aris99@gmail.com

\begin{abstract}
ABSTRAK
Latar Belakang: Kanker payudara (Carsinoma Mamae) adalah tumor ganas yang berasal dari kelenjar kulit, saluran kelenjar, dan jaringan di sebelah luar rongga dada. Kanker payudara dapat dideteksi lebih dini dengan cara SADARI untuk mengetahui stadium awal, sehingga pengobatan dini akan memperpanjang harapan hidup penderita kanker payudara. Pendidikan kesehatan merupakan suatu proses pembelajaran dalam menyampaikan pesan kesehatan, untuk meningkatkan pengetahuan dan keterampilan seseorang dalam menjaga kesehatannya Model pembelajaran word square dalam kegiatan intinya menggunakan susunan kotak kata seperti permainan teka-teki silang sehingga meningkatkan ketelitian dan membuat kritis dalam berfikir dalam mencari jawaban yang sudah ada pada kotak kata yang terdapat pada lembar kerja, ditambah bantuan alat peraga yang membuat dapat lebih bereksplorasi secara langsung dalam proses pembelajaran.

Tujuan: Penelitian ini bertujuan untuk mengetahui Efektifitas Pendidikan Kesehatan Dengan Model Word Square Terhadap Keterampilan Pemeriksaan Payudara Sendiri (SADARI) Di Desa Gembol, Ngawi.

Metode: Penelitian ini merupakan penelitian kuantitatif. Rancangan penelitian ini adalah rancangan quasi eksperimen design. Populasi penelitian ini adalah seluruh wanita usia remaja di Desa Gembol, Ngawi. Metode pengumpulan data menggunakan purposive sampling. Subyek penelitian ini seluruh wanita usia remaja di Desa Gembol, Ngawi yang berjumlah 30 orang dilakukan pada bulan Februari 2021. Analisa data dalam penelitian ini menggunakan Wilcoxon.

Hasil: Karakteristik usia responden menunjukkan bahwa rata-rata usia adalah 16 tahun dengan median 16, standar deviasi 0,490, usia termuda 15 tahun dan usia tertua 16 tahun, keterampilan sebelum pemberian pendidikan kesehatan dengan model word square mayoritas keterampilan kurang sebanyak 18 responden (60\%),
\end{abstract}


dan keterampilan sesudah pemberian pendidikan kesehatan dengan model word square mayoritas keterampilan baik sebanyak 22 responden $(73,4 \%)$. ketrampilan sebelum dan sesudah pemberian pendidikan kesehatan dengan model word square dengan nilai $p$ value $0,000<0,05$.

Simpulan: Pendidikan kesehatan metode word square efektif terhadap keterampilan pemeriksaan payudara sendiri (SADARI) di Desa Gembol, Ngawi.

Kata kunci: Pendidikan Kesehatan, Word Square, SADARI.

\begin{abstract}
Background: Breast cancer (Carsinoma Mamae) is a malignant tumor originating from the skin, soup ducts, and tissue outside the chest cavity. Breast cancer can be detected earlier by means of BSE to see the early stages, so that early treatment will be the life expectancy of breast cancer sufferers. Health education is a learning process in conveying health messages, to increase one's knowledge and skills in maintaining health. Square word learning model in its core activities uses word box arrangement such as crossword puzzles so as to increase accuracy and make critical thinking in finding answers that have been it is in the word box found on the worksheet, plus teaching aids that make it easier to explore more directly in the learning process.

The Purpose : This study aims to determine the effectiveness of Health Education with the Word Square Model on Self-Breast Examination Skills (BSE) in Gembol Village, Ngawi.
\end{abstract}

Method: This research is a quantitative research. The design of this research is a quasi experimental design. The population of this study were all adolescent women in the village of Gembol, Ngawi. The data collection method used purposive sampling. The subjects of this study were all female adolescents in Gembol Village, Ngawi, totaling 30 people, conducted in February 2021. Data analysis in this study used Wilcoxon.

Result: Characteristics of the age of the respondents show that the mean age is 16 years with a median of 16, standard deviation of 0.490, the youngest age is 15 years and the oldest is 16 years old, the skills before giving health education using the word square model, the majority of skills are less than 18 respondents $(60 \%)$, and skills after the provision of health education with the word square model, the majority of good skills were 22 respondents (73.4\%). skills before and after the provision of health education using the word square model with a $p$ value of $0.000<0.05$

Conclusion: Health education with the word square method is effective for breast self-examination skills (BSE) in Gembol Village, Ngaw

Key words: Health Education, Word Square, Breast Self-Examination (BSE) 


\section{PENDAHULUAN}

Kanker payudara (Carsinoma Mamae) adalah tumor ganas yang berasal dari kelenjar kulit, saluran kelenjar, dan jaringan di sebelah luar rongga dada. Sel kanker payudara dapat bersembunyi di dalam tubuh kita selama bertahun-tahun tanpa kita ketahui dan tiba-tiba aktif menjadi tumor ganas atau kanker (American Cancer Society, 2016).

Istilah kanker payudara merujuk pada tumor ganas yang telah berkembang dari sel-sel yang ada di dalam payudara. Payudara secara umum terdiri dari dua tipe jaringan, jaringan glandular (kelenjar) dan jaringan stromal (penopang). Jaringan kelenjar mencangkup kelenjar susu (lobules) dan saluran susu (the milk passage, milk duct). Sedangkan jaringan penopang meliputi jaringan lemak dan jaringan lymphatic, sebuah jaringan yang berisi system kekebalan yang bertugas mengeluarkan cairan dan kotoran selular (Utami, 2012).

Kejadian kanker payudara adalah kanker terbanyak kedua di dunia yang terjadi pada perempuan. Menurut data World Health Organization (2014), insiden kanker meningkat dari 12,7 juta kasus pada tahun 2008 menjadi 14,1 juta kasus pada tahun 2012. Sedangkan jumlah kematian meningkat dari 7,6 juta orang pada tahun 2008 menjadi 8,2 juta pada tahun 2012. Diperkirakan pada 2030 insiden kanker dapat mencapai 26 juta orang dan 17 juta di antaranya meninggal akibat kanker, terlebih untuk negara miskin dan berkembang kejadiannya akan lebih cepat.

Prevalensi penyakit kanker di Indonesia cukup tinggi. Berdasarkan data Riset Kesehatan Dasar (Riskesdas) tahun 2013, prevalensi tumor/kanker di Indonesia sebesar 1,4 per 1000 penduduk, atau sekitar 330.000 orang. Kanker tertinggi di Indonesia pada perempuan yakni kanker payudara dan kanker leher rahim. Sedangkan pada laki-laki yakni kanker paru dan kanker kolorektal. Berdasarkan estimasi Globocan, International Agency for Research on Cancer (IARC) tahun 2012, insiden kanker payudara sebesar 40 per 100.000 perempuan, kanker leher rahim 17 per 100.000 perempuan, kanker paru 26 per 100.000 lakilaki, kanker kolorektal 16 per 100.000 laki-laki. Berdasarkan data Sistem Informasi Rumah Sakit (SIRS) tahun 2010, kasus rawat inap kanker payudara 12.014 kasus (28,7 \%), kanker leher Rahim 5.349 kasus (12,8\%) (InfoDatin Kemenkes RI, 2016).

Kanker payudara dapat dideteksi lebih dini dengan cara SADARI untuk mengetahui stadium awal, sehingga pengobatan dini akan memperpanjang harapan hidup penderita kanker payudara. Pemeriksaan payudara sendiri adalah pemeriksaan yang dilakukan oleh individu untuk mengetahui benjolan adanya kanker payudara. Menurut Suastina (2013), rendahnya pengetahuan wanita tentang penyakit kanker payudara akan memperlambat usaha deteksi dini sehingga menyebabkan banyak wanita kurang berminat untuk melakukan usaha deteksi dini dalam pencegahan kanker payudara. American Cancer Society (2011), menganjurkan bahwa SADARI perlu dilakukan oleh wanita usia 20 tahun atau lebih setiap bulannya yaitu pada hari ke-7 atau ke-10 setelah selesai haid. 
Pendidikan kesehatan terkait pemeriksaan dan pengobatan kanker payudara sangat direkomendasikan di Negara berkembang maupun di Negara maju (Fajriah et al., 2020). Pengetahuan perempuan tentang resiko dan manfaat dari deteksi dini kanker payudara berpengaruh positif terhadap keyakinan mereka tentang kesehatan, sikap dan perilaku, sehingga perawatan kesehatan professional dapat mengembangkan program kesehatan payudara yang efektif (Erbil, 2012). Melakukan SADARI akan menurunkan tingkat kematian akibat kanker payudara hingga 20\%, namun sayangnya wanita yang melakukan SADARI masih rendah (25-30\%) (Septiani \& Suara, 2013). Dengan adanya pengetahuan dan keterampilan yang cukup diharapkan para remaja akan mampu memotivasi diri mereka untuk melakukan tindakan pencegahan deteksi dini.

Pendidikan kesehatan merupakan suatu proses pembelajaran dalam menyampaikan pesan kesehatan, untuk meningkatkan pengetahuan dan keterampilan seseorang dalam menjaga kesehatannya. Pendidikan kesehatan sangat penting untuk menambah pengetahuan dan salah satu proses promosi kesehatan yang paling sederhana bagi setiap manusia dalam menjaga kesehatan tubuh (Notoatmojo, 2012). Pendidikan kesehatan bertujuan meningkatkan pengetahuan dan pemahaman tentang kebiasaan deteksi dini dan perilaku hidup sehat. Pendidikan kesehatan tentang SADARI bersifat menginformasikan kepada semua orang tentang cara melakukan deteksi dini kanker payudara, dengan demikian, diharapkan mampu mengubah sikap wanita untuk menjaga kesehatannya dan mampu untuk melakukan deteksi dini kanker payudara (Lestari, Priyadi, \& Besar, 2016).

Sarana untuk menyampaikan pendidikan kesehatan diperlukan sebuah media. Media promosi kesehatan digunakan untuk menampilkan pesan atau informasi kesehatan yang ingin disampaikan kepada seseorang sehingga dapat meningkatkan pengetahuan dan dapat mengubah kearah perilaku yang positif. Ada beberapa media yang digunakan dalam promosi kesehatan diantaranya yaitu media cetak, media elektronik, dan media luar ruangan (Notoadmodjo, 2012). Efektifitas media tidak dilihat dari seberapa canggihnya media tersebut dalam penggunaannya. Pendidikan kesehatan sangat efektif dalam meningkatkan pengetahuan dan keterampilan remaja putri mengenai SADARI, terlebih apabila dalam penyampaiannya ditunjang dengan metode yang terbukti efektif.Dalam penelitian Noviana dan Akmil (2013) Yang berjudul "Efektivitas Model Pembelajaran Word Square Dengan Bantuan Alat Peraga Pada Materi Geometri" menurut jurnal penelitian ini model pembelajaran word square dengan bantuan alat peraga adalah kombinasi yang bagus, karena model pembelajaran word square merupakan model pembelajaran yang menerapkan konsep belajar dari Contextual Teaching and Learning yaitu konsep belajar yang membantu guru mengaitkan antara materi yang diajarkan dengan situasi dunia nyata. Model pembelajaran word square dalam kegiatan intinya menggunakan susunan kotak kata seperti permainan teka-teki silang sehingga meningkatkan ketelitian dan membuat kritis dalam berfikir dalam mencari jawaban yang sudah ada pada kotak kata yang terdapat pada lembar kerja, ditambah bantuan alat peraga yang membuat dapat lebih bereksplorasi secara langsung dalam proses pembelajaran. 
Berdasarkan latar belakang di atas, penulis tertarik untuk melakukan penelitian tentang "Efektifitas Pendidikan Kesehatan Dengan Model Word Square Terhadap Keterampilan Pemeriksaan Payudara Sendiri (Sadari)"

\section{METODE PENELITIAN}

Penelitian ini merupakan penelitian kuantitatif. Rancangan penelitian ini adalah rancangan quasi eksperimen design. Populasi penelitian ini adalah seluruh wanita usia remaja di Desa Gembol, Ngawi. Metode pengumpulan data menggunakan purposive sampling. Subyek penelitian ini seluruh wanita usia remaja di di Desa Gembol, Ngawi yang berjumlah 30 orang dilakukan pada bulan Februari 2021.

Pada penelitian ini menggunakan observasi yang digunakan untuk mencatat karakteristik responden yaitu nama (inisial) dan usia responden, lembar checklist langkah-langkah melakukan SADARI untuk menilai keterampilan responden. Skala pengukuran pada penelitian ini menggunakan skala Guttman. Dalam penelitian ini pengumpulan data primer dilakukan dengan membagikan kuesioner secara langsung kepada Rresponden, sedangkan pengumpulan data sekunder dilakukan dengan cara melihat dokumen-dokumen atau catatan-catatan yang mendukung data penelitian. Analisa data dalam penelitian ini menggunakan Wilcoxon.

\section{HASIL DAN PEMBAHASAN}

\section{Hasil}

Tabel 1 Distribusi Frekwensi Karakteristik Responden Usia

\begin{tabular}{cccccc}
\hline $\begin{array}{c}\text { Karakteristik } \\
\text { Usia }\end{array}$ & \multicolumn{5}{c}{ Penilaian } \\
\cline { 2 - 6 } & Min & Max & Mean & SD & Median \\
\hline & 15 & 16 & 15,62 & 0,490 & 16 \\
\hline
\end{tabular}

Tabel 1 menunjukkan bahwa rata-rata usia adalah 16 tahun dengan median 16, standar deviasi 0,490 , usia termuda 15 tahun dan usia tertua 16 tahun.

Tabel 2 Distribusi Frekwensi Karakteristik Responden Berdasarkan Ketrampilan Sebelum Pendidikan Kesehatan Dengan Model Word Square

\begin{tabular}{|c|c|c|}
\hline Ketrampilan & Frekuensi & $\%$ \\
\hline Baik & 5 & 16,7 \\
\hline Cukup & 7 & 23,3 \\
\hline Kurang & 18 & 60 \\
\hline Total & 30 & 100 \\
\hline
\end{tabular}

Tabel 2 diketahui bahwa mayoritas penelitian ketrampilan sebelum pemberian Pendidikan Kesehatan Dengan Model Word Square menunjukan ketrampilan kurang sebanyak 18 responden $(60 \%)$. 
Tabel 3 Distribusi Frekwensi Karakteristik Responden Berdasarkan Ketrampilan Sebelum Pendidikan Kesehatan Dengan Model Word Square

\begin{tabular}{|c|c|c|}
\hline Ketrampilan & Frekuensi & $\%$ \\
\hline Baik & 22 & 73,4 \\
\hline Cukup & 8 & 26,6 \\
\hline Kurang & - & - \\
\hline Total & 30 & 100 \\
\hline
\end{tabular}

Tabel 3 diketahui bahwa mayoritas penelitian ketrampilan sebelum pemberian pendidikan kesehatan dengan model word square menunjukan ketrampilan baik sebanyak 22 responden $(73,4 \%)$.

Tabel 4 Analisa Uji Wilcoxon Efektifitas Pendidikan Kesehatan Dengan Model Word Square Terhadap Keterampilan Pemeriksaan Payudara Sendiri (SADARI)

\begin{tabular}{ccc}
\hline & $\mathbf{Z}$ & P-value \\
\cline { 2 - 3 } Asymp. Sig. (2-tailed) & $-5,773$ & 0,000 \\
\hline
\end{tabular}

Tabel 4 diketahui ketrampilan sebelum dan sesudah pemberian pendidikan kesehatan dengan model word square dengan nilai $p$ value $0,000<0,05$ maka Ho di tolak berarti ada perbedaan antara sebelum dan sesudah pemberian pendidikan kesehatan dengan model word square SADARI terhadap ketrampilan SADARI di Desa Gembol, Ngawi.

\section{Pembahasan}

Berdasarkan Tabel 1. Hasil penelitian ini menunjukkan rata-rata usia adalah 16 tahun dengan usia termuda 15 tahun dan usia tertua 16. Usia responden termasuk dalam kategori usia remaja awal yaitu usia 12-16 tahun (Depkes, 2009). Fase remaja manusia akan mengalami banyak sekali perubahan karena tubuh sedang dalam masa pertumbuhan dan perkembangan. Remaja akan mengalami perubahan baik fisik maupun psikisnya. Secara fisik, remaja akan mengalami perkembangan payudara salah satunya. Payudara remaja akan membesar (Yulinda \& Fitriyah, 2018). Adanya perubahan pada bentuk payudaranya, remaja akan cenderung lebih memperhatikan perubahan-perubahan pada organ tersebut. Mereka akan mulai merasa penasaran dan akan mulai melihat bahkan meraba payudara mereka sendiri untuk merasakan perubahan tersebut. Namun tidak sedikit pula remaja yang merasa tidak siap dengan perubahan fisik yang dialaminya. Hal tersebut dapat menyebabkan timbulnya rasa malu, cemas dan merasa ada masalah pada kondisi fisik mereka. Sehingga mereka akan mulai merasa asing dengan tubuh mereka sendiri (Sulastri, 2012). Masa remaja adalah masa untuk mencari jati diri dan remaja mulai ingin menunjukkan perannya yakni mendapat sense of individual identity. Hal ini mencakup pembuatan keputusan, melakukan suatu tindakan dan juga menjaga harga diri. Sehingga hal ini sering 
dikaitkan dengan keputusan dari seorang remaja dalam menerapkan ilmu pengetahuan yang dimilikinya dalam konteks ini adalah keterampilan remaja dalam melakukan SADARI (Pieters, 2011).

Berdasarkan Tabel 2. Hasil penelitian ini menunjukkan keterampilan sebelum pemberian pendidikan kesehatan dengan model word square mayoritas keterampilan kurang sebanyak 18 responden (60\%). Pentingnya deteksi dini tumor atau kanker payudara dalam hal ini adalah untuk mendeteksi kanker payudara sejak dini dan teknik ini perlu dikuasai dan dilakukan oleh remaja putri. Sesuai dengan pengertian SADARI itu sendiri yaitu usaha atau cara pemeriksaan payudara yang secara teratur dan sistemik dilakukan oleh wanita itu sendiri yang merupakan bagian tidak terpisahkan dari program screening atau deteksi dini (Romauli,2012). Melakukan SADARI memerlukan keterampilan dalam melakukannya. Rendahnya kemampuan remaja putri dalam melakukan SADARI dapat terjadi karena selama ini informasi yang berkaitan dengan SADARI baru berbentuk teori dan belum mendapatkan pelatihan bagaimana cara mempraktekkan SADARI secara benar (Ayu \& Rilyani, 2016). Tahapan keterampilan dalam 4 tingkatan yaitu: pertama individu mulai mengenal dan memilih berbagai objek sehubungan dengan tindakan yang akan diambil, kemudian individu sudah mampu melalukan sesuatu sesuai dengan urutan yang benar, tahap selanjutnya jika individu sudah mampu melakukan sesuatu dengan benar maka secara otomatis sesuatu itu akan menjadi kebiasaan dan pada tahap akhir individu telah beradaptasi dengan keterampilan atau praktik yang sudah berkembang dengan baik (Mufida dkk, 2015). Faktor yang dapat mempengaruhi keterampilan seseorang seperti umur, pendidikan, pengetahuan, sikap, keyakinan, fasilitas/sarana kesehatan, lingkungan fisik, dan faktor penguat seperti tenanga kesehatan (Robbin, 2014).

Berdasarkan Tabel 3. Hasil penelitian ini menunjukkan keterampilan sesudah pemberian pendidikan kesehatan dengan model word square mayoritas keterampilan baik sebanyak 22 responden $(73,4 \%)$. Sejalan dengan hasil penelitian Syafitri (2017) menggambarkan peningkatan keterampilan peserta setelah mengikuti pelatihan SADARI. Pendidikan kesehatan merupakan pendidikan yang tidak lepas dari proses belajar karena proses belajar itu ada dalam rangka mencapai tujuan pendidikan. Sebelum terjadi perubahan perilaku, seseorang akan mempunyai persepsi terhadap apa yang akan dijalaninya sehingga menimbulkan persepsi yang berhubungan dengan tingkat pengetahuan yang diperoleh dari informasi, sehingga bila informasi yang diterima kurang jelas, hasil pembelajaran yang didapat juga tidak optimal maka keterampilan akan meningkat (Sari, 2012). Manfaat media antara lain yaitu dapat memperjelas materi yang disampaikan, mengatasi keterbatasan ruang, waktu dan daya indera, serta mengatasi sikap pasif dan dapat merangsang indera sasaran pendidikan (Suiraoka \& Supariasa, 2012). Efendy, Ferry \& Makhfudli (2009) mengatakan sebagian besar pengetahuan manusia diperoleh melalui mata dan telinga seperti poster, buklet, leaflet, slide atau informasi yang berupa tulisan dan informasi yang berbentuk suara seperti ceramah, penyuluhan atau video yang membantu menstimulasi penginderaan dalam proses pembelajaran. Model pembelajaran 
Word Square merupakan model pengembangan dari metode ceramah yang diperkaya dan berorientasi kepada keaktifan peserta didik dalam pembelajaran. Model ini juga merupakan model yang memadukan kemampuan menjawab pertanyaan dengan kejelian dalam mencocokkan jawaban pada kotak-kotak jawaban mirip seperti mengisi "Teka-Teki Silang" tetapi bedanya jawabannya sudah ada namun disamarkan dengan menambahkan kotak tambahan dengan sembarang huruf/angka penyamar atau pengecoh (Kurniasih, Imas \& Berlin, 2016). Hasil penelitian Ernawati dkk (2013), mengatakan ada hubungan yang bermakna dari penyuluhan kesehatan terhadap peningkatan pengetahuan.

Tabel 4. Hasil penelitian ini didapatkan bahwa pendidikan kesehatan metode word square efektif terhadap keterampilan pemeriksaan payudara sendiri (SADARI). Nilai signifikansi $p$ value (2-tailed) sebesar 0,000 yang berarti $<0,05$ maka H0 ditolak dan $\mathrm{Ha}$ di terima bahwa terdapat perbedaan yang signifikan antara ketrampilan sebelum dan sesudah pendidikan kesehatan sehingga dapat disimpulkan pendidikan kesehatan metode word square efektif dalam terhadap keterampilan pemeriksaan payudara sendiri (SADARI) di Desa Gembol, Ngawi. Hasil penelitian ini mendukung penelitian yang dilakukan oleh Suratman, Ngatman \& Warsiti (2014) menunjukan penggunaan model Word Square dapat meningkatkan hasil belajar kelas IV SD. Sejalan dengan hasil penelitian Yulianti, Suhartono \& Kartika (2013) mengatakan penggunaan model Word Square dapat meningkatkan penguasaan kosakata bahasa Inggris siswa kelas IV SD.

Maulana (2009) mengemukakan bahwa sasaran dalam promosi kesehatan bagi individu atau keluarga yaitu diharapakan individu memperoleh informasi kesehatan melalui media masa atau secara langsung dengan cara penyuluhan. Model pembelajaran word sqaure merupakan model pembelajaran yang memadukan kemampuan menjawab pertanyaan dengan kejelian dalam mencocokan jawaban pada kotak-kotak jawaban. Model ini mirip seperti mengisi Teka-Teki Silang tetapi bedanya jawabannya sudah ada namun disamarkan dengan menambahkan kotak tambahan dengan sembarang huruf penyamar atau pengecoh (Suyatno, 2011). Menurut Widiyanto (2020) mengatakan adanya pemberian informasi kesehatan tyang perlu diterpakan oleh masyarakat di harapkan dapat memotivasi masyarakat dan memberdayakan masyarakat untuk bisa memperhatikan kesehatanya sehingga masyarakat memiliki kualitas hidup yang optimal.

\section{SIMPULAN DAN SARAN}

\section{Simpulan}

Karakteristik usia responden menunjukkan bahwa rata-rata usia adalah 16 tahun dengan median 16, standar deviasi 0,490, usia termuda 15 tahun dan usia tertua 16 tahun, keterampilan sebelum pemberian pendidikan kesehatan dengan model word square mayoritas keterampilan kurang sebanyak 18 responden (60\%), dan keterampilan sesudah pemberian pendidikan kesehatan dengan model word square mayoritas keterampilan baik sebanyak 22 responden $(73,4 \%)$. ketrampilan sebelum dan sesudah pemberian pendidikan kesehatan dengan model word square 
dengan nilai $p$ value $0,000<0,05$ maka Ho di tolak berarti ada perbedaan antara sebelum dan sesudah pemberian pendidikan kesehatan dengan model word square SADARI terhadap ketrampilan SADARI di Desa Gembol, Ngawi. didapatkan bahwa pendidikan kesehatan metode word square efektif terhadap keterampilan pemeriksaan payudara sendiri (SADARI) di Desa Gembol, Ngawi.

\section{Saran}

Bagi wanita usia remaja dari hasil penelitian ini diharapkan untuk meningkatkan pengetahuan dan keterampilan pemeriksaan payudara sendiri (SADARI) melalui media masa, baik surat kabar, majalah, sosial media dan tenaga kesehatan sehingga selain pengetahuan tentang pemeriksaan payudara sendiri (SADARI) nya meningkat juga dapat meningkatkan upaya sebagai deteksi dini kanker payudara. Bagi Tenaga Kesehatan diharapkan dapat berkerja sama dengan intitusi pendidikan guna memberikan penyuluhan kesehatan secara rutin kepada masyarakat khususnya tentang pemeriksaan payudara sendiri (SADARI).

\section{DAFTAR PUSTAKA}

American Cancer Society. (2016). Cancer Facts And Figures 2016, diakses 3 Oktober 2020, <http://www.cancer.org>.

Efendy, Ferry dan Makhfudli.(2009). Keperawatan Kesehatan Komunitas Teori dan Praktik dalam Keperawatan. Jakarta : Salemba Medika

Erbil, NB. (2012). Beliefs, Attitude, and Behaviour of Turkish Women about Breast Cancer and Breast-Self Examination According to a Turkish Version of Champion Health Belief Model Scale. Asian Pasific Journal of Cancer Prevention. 13(11):22-29

Fajriah, A. S., Respati, S. H., \& Murti, B. (2020). Application of Health Belief Model and Theory of Planned Behavior on Factors Affecting Breast Self Examination among University Students. 4, 246-257. https://doi.org/10.26911/the 7thicph.02.42

Kurniasih, Imas dan Berlin Sani.(2016). Ragam Pengembangan Model Pembelajaran Untuk Peningkatan Profesionalitas Guru. Jakarta: Kata Pena

Lestari, DP., Priyadi, NP., \& Besar, TH. (2016). Pengaruh Penyuluhan Kesehatan Terhadap Pengetahuan, Sikap dan Praktik Periksa Payudara Sendiri (SADARI) Santri Putri Pondok Pesantren Dawar Kabupaten Boyolali, Jurnal Kesehatan Masyarakat. 4.(5):1-8

Notoatmodjo, S. (2012). Promosi Kesehatan Dan Perilaku Kesehatan. Jakarta : Rineka Cipta.

Savitri, A, dkk., (2015). Kupas Tuntas Kanker Payudara, Leher Rahim Dan Rahim. Yogyakarta : Pustaka Press.

Septiani, S dan Suara, M. (2012). Faktor-Faktor yang Berhubungan dengan Perilaku Pemeriksaan Payudara Sendiri (Sadari) Pada Siswa SMAN 62 Jakarta, Jurnal Ilmiah Kesehatan. vol. 5 (1):1-10 
Yulianti R, Suhartono, Kartika C.(2013). Penggunaan Model Word Square Dalam Peningkatan Penguasaan Kosakata Bahasa Inggris Siswa Kelas IV SD. PGSD FKIP UNS. http://download.portalgaruda.org/article.

Lovepink Indonesia. (2018). Langkah SADARI (Periksa Payudara Sendiri), diakses 25 Oktober 2018, < https://www.youtube.com/watch?v=c1v74j7$\mathrm{SYM}>$.

Soemitro, MP. (2012). Blak-Blakan Kanker Payudara : Temukan Sedini Mungkin. Bandung : Qanita.

Suastina, Ayu. (2013). Pengaruh Penyuluhan Terhadap Pengetahuan dan Sikap Ibu PKK Tentang Pemeriksaan Payudara Sendiri (SADARI). Artikel Ilmiah. 2 (2):11-17

Syahfitri, EH. (2012). Gambaran Pengetahuan dan Sikap Remaja Putri tentang SADARI di SMA Ahmad Yani Binjai. Medan : Karya Tulis Ilmiah.

Utami, Sri. (2018). Kanker Payudara. Jakarta Selatan : Oryza.

Widiyanto A, Atmojo JT, Fajriah AS, Putri SI, Akbar PS (2020). Pendidikan Kesehatan Pencegahan Hipertensi. 1(2):96-190

World Health Organization. (2014). Breast Cancer, diakses 1 Oktober 2020, $<$ http://www.who.go.org>. 